\title{
Magdalena Fedorowicz
}

Katedra Prawa Finansowego

Wydział Prawa i Administracji UAM w Poznaniu

e-mail: magdalena.fedorowicz@amu.edu.pl

\section{Kilka uwag o zjawisku samoregulacji na rynku bankowym w nowej architekturze nadzorczej}

\section{STRESZCZENIE}

Celem opracowania jest analiza zjawiska samoregulacji i jej materii oraz znaczenia samoregulacji dla funkcjonowania instytucji kredytowych w nowej architekturze nadzorczej, ukształtowanej w wyniku fundamentalnych zmian w prawie rynku finansowego UE po utworzeniu Europejskiego Systemu Nadzoru Finansowego oraz Europejskiej Unii Bankowej. Teza i wnioski artykułu dotyczą twierdzeń o ograniczeniu samoregulacji na rynku finansowym (tu bankowym) i zmianach w treści pojęcia „samoregulacja” oraz przesunięciu normatywnego punktu ciężkości na regulowanie spraw rynku finansowego za pomocą wiążących norm i instrumentów oddziaływania. Szczególnym przedmiotem analiz uczyniono rozwinięte w ostatnim czasie postanowienia ustawy Prawo bankowe dotyczące m.in. systemu zarządzania ryzykiem oraz kontroli wewnętrznej, a także whistleblowing, dla zilustrowania wniosków prezentowanych w opracowaniu.

\section{SŁOWA KLUCZOWE}

samoregulacja, rynek finansowy UE, architektura nadzoru w UE, materie samoregulacji, kontrola wewnętrzna w bankach

\section{Uwagi wstępne}

W dobie znacznego przeregulowania obserwowanego na rynku finansowym i konieczności uwzględniania przez instytucje finansowe regulacji krajowych oraz unijnych, szczególnego znaczenia nabiera odpowiedź na pytanie o sens prawny i zakres możliwości samoregulacyjnych instytucji finansowych, w tym w szczególności w sektorze bankowym. Zagadnienie to było już wcześniej przedmiotem analiz prawniczych, zarówno bardziej praktycznych ${ }^{1}$, jak

1 D. Wojtczak-Samoraj, Soft law i mechanizmy nielegislacyjne jako instrumenty integracji rynku usług bankowych Unii Europejskiej, „Monitor Prawa Bankowego” 2012, nr 1, s. 58 i n. 
i teoretycznych ${ }^{2}$. Teraz jednak, z uwagi na zmiany regulacyjne na rynku finansowym, wypada postawić pytanie, po pierwsze, o zmiany w pojęciu „samoregulacji”, jej treści, a także wpływ zjawiska samoregulacji na funkcjonowanie instytucji finansowych na rynku finansowym UE. Jest to również w istocie pytanie o zakres pewnej autonomii regulacyjnej, którą w zakreślonych ramach prawnych „obdarowywane” są instytucje finansowe w zakresie, jak wcześniej przybliżano w piśmiennictwie, soft law, hard law, self-regulation czy tzw. co-regulation ${ }^{3}$. Po drugie powstaje również pytanie, czy w świetle zmian legislacyjnych po kryzysie finansowym można jeszcze formułować twierdzenia o istnieniu zjawiska samoregulacji na rynku finansowym (w niniejszym opracowaniu - na rynku bankowym) w zakresie wybranego do analizy zagadnienia kontroli wewnętrznej i wewnątrzbankowego systemu zarządzania ryzykiem jako zagadnień, $\mathrm{w}$ których może realizować się idea samoregulacji ${ }^{4}$. Jest to tym bardziej istotne, że przecież na rynku finansowym UE doszło do zmiany paradygmatu regulacyjnego na nadzorczy, a skoro istotą nadzoru jest zasadniczo wiążące przesądzanie o sytuacji prawnej podmiotu podległego kompetencji czy też określanie wiążących, czy nawet niewiążących wzorców normatywnych powinnego zachowania „wymuszających” swoje stosowanie ${ }^{5}$, to ogranicza to możliwości samoregulacyjne instytucji finansowych.

Inflacja przepisów na rynku finansowym uprawnia też do postawienia pytań o zakres normatywizacji treści regulacyjnych na tym rynku, a w szczególności, czy miękkie formy regulacji rynku finansowego (tzw. soft law rynku finansowego) nie podlegają stopniowej i postępującej normatywizacji, ograniczając tym samym zakres samoregulacji instytucji finansowych. Wydaje się to tym bardziej istotne, że przecież pojęcie „samoregulacja” nie jest pojęciem legalnym, nie ma definicji legalnej, a stanowi rezultat doktrynalnych poszukiwań definicyjnych. Asumpt do podjęcia tej problematyki dało nie tylko powszechne przekonanie przedstawicieli doktryny prawa rynku finansowego o zmianie paradygmatu regulacyjnego, lecz także fundamentalne zmiany w unijnej architekturze finansowej ${ }^{6}$, związane z powstaniem Europejskiego Systemu Nadzoru Finansowego (ESNF) ${ }^{7}$, wdrożeniem dyrek-

2 Obszernie nt. zasadności wyróżnienia regulacji obligatoryjnej i samoregulacji zob. T. Nieborak, Samoregulacja a rola państwa $w$ sferze regulacji rynku finansowego, w: Własność $i$ kontrola $w$ teorii i praktyce, cz. 1, red. B. Polszakiewicz, J. Boehlke, (Ekonomia i Prawo, t. 3), Wydawnictwo Uniwersytetu Mikołaja Kopernika, Toruń 2007, s. 207 i n.

3 Zob. m.in. D. Wojtczak-Samoraj, op. cit., s. 58.

4 Zob. m.in. T. Nieborak, Samoregulacja a rola państwa..., s. 207 i n.

5 M. Fedorowicz, Nadzór nad rynkiem finansowym Unii Europejskiej, Difin, Warszawa 2013, s. 163.

6 A. Jurkowska-Zeidler, Bezpieczeństwo rynku finansowego w świetle prawa Unii Europejskiej, Wolters Kluwer, Warszawa 2008, s. 11 i cyt. tam literatura; eadem, Zmiany w otoczeniu regulacyjnym rynku finansowego Unii Europejskiej, $\mathrm{w}$ : XXV lat przeobrażeń w prawie finansowym i prawie podatkowym. Ocena dokonań $i$ wnioski na przyszłość, red. Z. Ofiarski, Wydział Prawa i Administracji Uniwersytetu Szczecińskiego, Szczecin 2014, s. 714; zob. też A. Michór, Nowa europejska architektura nadzoru nad rynkiem bankowym, „Bezpieczny Bank” 2011, nr 1, s. 71-90.

7 M. Fedorowicz, Nadzór nad rynkiem finansowym..., passim. 
tywy CRD IV ${ }^{8}$ i stosowaniem rozporządzenia CRR $^{9}$ oraz ustanowieniem Europejskiej Unii Bankowej ${ }^{10}$.

Celem niniejszego opracowania jest zatem udzielenie odpowiedzi na pytanie o analizę pojęcia „samoregulacji” oraz jego znaczenie dla funkcjonowania instytucji kredytowych, z uwagi na ograniczone ramy opracowania, w sektorze bankowym rynku finansowego UE (w ramach kontroli wewnętrznej i wewnątrzbankowego systemu zarządzania ryzykiem), który zazwyczaj jest traktowany jako najstarszy i wzorcowy dla pozostałych segmentów rynku. Przy czym podjęte zamierzenie badawcze nie ma w swoim założeniu stanowić kolejnego ujęcia z zakresu corporate governance czy governance gospodarczego ${ }^{11}$ ani rozważań compliance, mimo że funkcjonalnie jest $\mathrm{z}$ nimi połączone, a stanowić ma raczej propozycję ramowego ujęcia zakresu możliwych i dopuszczalnych granic wewnątrzregulacyjnych dla działalności instytucji kredytowych (finansowych) na rynku finansowym w sektorze bankowym, oczywiście w przewidzianych obowiązujących ramach prawnych, wynikających z prawa unijnego i krajowego. Zadanie to jest zatem bardziej przynależne do zagadnień teorii prawa rynku finansowego, a jego realizacja pomóc ma w doprecyzowaniu i wytyczeniu granic zjawiska samoregulacji dla instytucji kredytowych we współczesnej architekturze nadzorczej i może wykazywać również doniosłość praktyczną.

Tezą niniejszego opracowania jest twierdzenie o wywołanym zmianami prawnymi w pokryzysowej architekturze nadzorczej ograniczeniu samoregulacji na rynku finansowym (tu bankowym) i zmianach w treści doktrynalnego pojęcia „samoregulacja” oraz przesunięciu normatywnego punktu ciężkości na regulowanie spraw rynku finansowego za pomocą wiążących norm i instrumentów oddziaływania, a w razie posługiwania się soft law tworzenie mechanizmów i instrumentów „wymuszających” przestrzeganie i stosowanie soft law rynku finansowego UE. W artykule niniejszym podejmowana jest zatem analiza pojęcia i zjawiska „samoregulacji” oraz jego współczesnych funkcji na mocno zmodyfikowanym działaniami legislacyjnymi rynku finansowym UE w ujęciu metodologii właściwej naukom prawnym.

8 Dyrektywa 2013/36/UE Parlamentu Europejskiego i Rady z dnia 26 czerwca 2013 r. w sprawie warunków dopuszczenia instytucji kredytowych do działalności oraz nadzoru ostrożnościowego nad instytucjami kredytowymi i firmami inwestycyjnymi, zmieniająca dyrektywę 2002/87/WE i uchylająca dyrektywy 2006/48/WE oraz 2006/49/WE, Dz.Urz. UE L 176 z 27.06.2013, s. 338, dalej dyrektywa CRD IV.

9 Rozporządzenie Parlamentu Europejskiego i Rady nr 575/2013 z dnia 26 czerwca 2013 r. w sprawie wymogów ostrożnościowych dla instytucji kredytowych i firm inwestycyjnych, zmieniające rozporządzenie (UE) nr 648/2012, Dz.Urz. UE L 176 z 27.06.2013, s. 1, dalej rozporządzenie CRR.

10 A. Jurkowska-Zeidler, Europejska Unia Bankowa. Architektura instytucjonalna, w: Instytucje prawnofinansowe w warunkach kryzysu gospodarczego, red. W. Miemiec, K. Sawicka, Wolters Kluwer, Warszawa 2014, s. 593; eadem, Prawo Unii Bankowej, „Analiza Natolińska” 2016, nr 1, s. 16; T. Knepka, Rola Europejskiego Banku Centralnego w zapewnieniu stabilności rynku finansowego Unii Europejskiej, Instytut Wydawniczy EuroPrawo, Warszawa 2017, passim.

11 Zob. obszerniej M. Menkes, Governance gospodarczy. Studium prawnomiędzynarodowe, C.H. Beck, Warszawa 2016, passim. 


\section{Pojęcie samoregulacji}

Przez pojęcie samoregulacji instytucji finansowych rozumieć można kompetencję instytucji finansowych (tu instytucji kredytowych) do wydawania norm postępowania, tworzenia standardów postępowania, w tym również etycznych, służących wewnętrznej organizacji i funkcjonowaniu tych instytucji w przewidzianych, obowiązujących ramach prawnych, określonych zarówno w prawie rynku finansowego na poziomie UE, jak i krajowym ${ }^{12}$. Oczywiście ramy prawne dopuszczalnej wewnętrznej autonomii regulacyjnej instytucji finansowych określone są przez prawodawcę unijnego i ustawodawcę krajowego, a także regulatorów, nadzorców rynku finansowego na poziomie krajowym i unijnym. To wskazane podmioty wyznaczają instytucjom finansowym sferę dopuszczalnego i pożądanego zakresu ich wewnętrznej regulacji, a zatem możliwą do zagospodarowania sferę autonomii regulacyjnej, której granice zawarte są w obowiązujących aktach prawa krajowego i UE. Przy czym użyte sformułowanie autonomii regulacyjnej dotyczy możliwej (dopuszczalnej) do zagospodarowania sfery wewnętrznej organizacji czy zarządzania instytucjami finansowymi, także wprowadzania norm postępowania czy norm etycznych w działalności bankowej (finansowej), wiązanej np. ze społeczną odpowiedzialnością biznesu, standardem obsługi klientów czy strategiami działalności biznesowej oraz kodeksami etyki bankowej.

W praktyce oznacza to, że instytucje, wydając swoje strategie, polityki czy programy działania, realizują ideę samoregulacji. Można i trzeba jednak również zwrócić uwagę na to, że samoregulacja możliwa jest zarówno w obszarach nieobjętych dotąd aktami wiążącymi prawnie, jak i w obszarach już unormowanych, gdzie akty prawne wyznaczają pewien standard normatywny, który może być zintensyfikowany przez instytucje finansowe, m.in. dla ochrony klienta w celu prowadzenia działalności opartej nie w minimalnym (wyznaczonym aktami prawa), ale maksymalnym standardzie regulacyjnym, uwzględnianym dzięki soft law na rynku finansowym czy właśnie dzięki aktywnościom samoregulacyjnym instytucji finansowych, a w tym również corporate governance czy compliance.

W wyniku zmian legislacyjnych na rynku finansowym obserwowalna jest jednak silna tendencja do, po pierwsze, normatywizacji przyjętych już sposobów postępowania instytucji finansowych, co m.in. przejawia się w znormatywizowanej ostatnio instytucji whisteblowing, po drugie, do normatywizacji dotychczasowego soft law w wiążące przepisy prawne, a po trzecie, swoistego normatywnego „zawłaszczania” dotąd nieuregulowanych obszarów stosunków prawnorynkowych na rynku finansowym UE. Wszystkie trzy wymienione obszary wpływają, jak należy uznać, ograniczająco na zdolności samoregulacyjne instytucji finansowych, co jest skutkiem kryzysu finansowego i zarazem przyjętej, nadzorczej filozofii regulacyjnej. 


\section{Materia samoregulacji}

Materię, która może być przedmiotem samoregulacji dokonywanej przez instytucje kredytowe można podzielić na materię pozytywną i negatywną. Do pozytywnej materii należałyby sprawy, które powinny lub mogą podlegać rozwinięciu w zakresie wewnętrznej regulacji przyjmowanej przez instytucje kredytowe. Z kolei do materii negatywnej zaliczyć należałoby te sprawy, które nie mogą podlegać uporządkowaniu w ramach samoregulacji. $\mathrm{Z}$ uwagi na zmianę paradygmatu regulacyjnego i rozwój unifikujących regulacji prawa rynku finansowego w formie rozporządzeń i BTS-ów ${ }^{13}$ wskazać można, że ubywa treści, które mogą stać się przedmiotem wewnątrzregulacyjnej aktywności banków, a w sytuacji, w której pojawiają się takie obszary, to jednak wiążące akty prawa coraz ściślej określają warunki brzegowe realizowania kompetencji wewnątrzregulacyjnych przez banki.

Ograniczeń w zakresie samoregulacji instytucji finansowych można również doszukiwać się w nałożonych na banki obowiązkach ujawnień ${ }^{14}$. Można wręcz wskazać, że obowiązki ujawnień, polityka wynagrodzeń, zagadnienia systemu zarządzania bankiem z jednej strony ograniczają zdolności samoregulacyjne banków, a z drugiej strony, wyznaczając obowiązki (określone w dużym stopniu w prawie UE), pozostawiają jednak wydzielony zakres autonomii dla przyjmowania wewnętrznych dokumentów bankowych.

Z uwagi na wskazane obszary możliwe do zagospodarowania przez instytucje finansowe w drodze działalności samoregulacyjnej można wyróżniać materie, w których samoregulacja jest możliwa i pożądana lub też materie, w których nie może i nie powinna być realizowana. Jak już podkreślono, obszar badawczy w niniejszym opracowaniu ograniczony został do wybranych zagadnień ustawy z dnia 29 sierpnia 1997 r. Prawo bankowe ${ }^{15}$ (dalej jako ustawa Prawo bankowe) i wykonującego art. 9f tej ustawy rozporządzenia Ministra Finansów w sprawie systemu zarządzania ryzykiem i systemu kontroli wewnętrznej, polityki wynagrodzeń oraz szczegółowego sposobu szacowania kapitału wewnętrznego w bankach ${ }^{16}$ (dalej jako rozporządzenie MF z 2017 r.), które ma m.in. za zadanie uzupełnienie wdrożenia dyrektywy CRD IV i służy również stosowaniu rozporządzenia CRR. Samoregulacja instytucji kredytowych nie odbywa się bowiem w próżni prawnej. Z jednej strony można rekonstruować $\mathrm{z}$ aktów prawnych (ustaw krajowych i rozporządzeń unijnych) kompetencje dla instytucji finansowych do przyjmowania określonych norm postępowania, istotnych dla działalności wewnętrznej banków, z drugiej strony natomiast obowiązujące przepisy wyznaczają dopuszczalny zakres działalności regulacyjnej instytucji finansowych.

Na gruncie prawa bankowego samoregulacyjne znaczenie mają przede wszystkim postanowienia ustawy Prawo bankowe dotyczące funkcjonującego w banku systemu zarządzania. Zgodnie z art. 9 ust. 2 ustawy Prawo bankowe, system zarządzania stanowi, po pierwsze, zbiór zasad i mechanizmów odnoszących się do procesów decyzyjnych, zachodzących

13 Wiążące standardy techniczne (ang. Binding Technical Standards, BTS).

14 Zestawienie treści regulacji CRR/ CRD IV objętych obowiązkiem ujawnień zob. M. Fedorowicz, Obowiązki informacyjne i ujawnienia nałożone na banki w świetle rozporządzenia CRR, komentarz praktyczny Lex dla Banków nr 193490, s. 1-13.

15 Tekst jedn.: Dz.U. z 2017 r., poz. 1876 ze zm.

16 Dz.U. z 2017 r., poz. 637. 
w banku, po drugie, odnosi się również do oceny prowadzonej działalności bankowej, a po trzecie, co stanowi novum na gruncie prawa bankowego, dotyczy także procedury anonimowego zgłaszania wskazanemu członkowi zarządu, a w szczególnych przypadkach radzie nadzorczej banku, naruszeń prawa oraz obowiązujących w banku procedur i standardów etycznych (tzw. whistleblowing). Treść procedur związanych z instytucją whistleblowing wyznacza art. 9 ust. $2 \mathrm{~b}$ ustawy Prawo bankowe, zgodnie z którym na banku spoczywa obowiązek zapewnienia pracownikom zgłaszającym naruszenia ochrony przed działaniami o charakterze represyjnym, dyskryminacyjnym lub innymi rodzajami niesprawiedliwego traktowania. Oznacza to dla banku powinność stworzenia procedur, które gwarantować będą wskazane cele i instrumenty prawidłowej realizacji instytucji whistleblowing, tak jak uregulowano to w art. 9 ust. $2 \mathrm{~b}$ ustawy Prawo bankowe. Warto dodać, że zgłaszanie naruszeń, wynikające $\mathrm{z}$ art. 71 ust. 3 dyrektywy CRD IV, uszczegółowione zostało w rozdziale 5 rozporządzenia MF z 2017 r. - Procedury anonimowego zgłaszania naruszeń prawa oraz obowiązujących w banku procedur i standardów etycznych.

Jak już podkreślano w literaturze, obszarem ważnym dla zjawiska samoregulacji jest kontrola wewnętrzna $w$ bankach, postrzegana obecnie jako cały system ${ }^{17}$. System ten opiera się na pojmowaniu kontroli wewnętrznej jako systemu odrębnego od systemu zarządzania ryzykiem, z własnymi mechanizmami kontroli wewnętrznej (mechanizmami kontrolnymi) i mechanizmami kontroli ryzyka. Trzeba jednak zauważyć, że również w obszarze kontroli wewnętrznej pojawia się coraz więcej elementów wyznaczających bankom preferowany sposób postępowania. Warto w tym miejscu przywołać chociażby Rekomendację $\mathrm{H}$ dotyczącą systemu kontroli wewnętrznej w bankach z kwietnia 2017 r., w której przewidziano, że „Postanowienia [...] Rekomendacji mają pierwszeństwo w stosowaniu przed postanowieniami w zakresie kontroli wewnętrznej, o których mowa w innych rekomendacjach i wytycznych $\mathrm{KNF}^{\prime 18}$. Jak wiadomo, rekomendacje stanowią zbiór zasad dotyczących dobrych praktyk w określonym zakresie, ale dla rozważań prowadzonych w niniejszym opracowaniu fundamentalne jest stwierdzenie, że rekomendacje są wskazaniem przez Komisję Nadzoru Finansowego pożądanego sposobu prowadzenia przez bank działalności w tych przypadkach, gdy przepisy prawa nie regulują tego lub czynią to w sposób niewystarczająco dookreślony, a istnieją przesłanki dla ukształtowania dobrej praktyki rynkowej w określonym obszarze działalności ${ }^{19}$. Tym samym, mimo że rekomendacje nie są prawnie wiążące, to jednak banki stosują się do nich $\mathrm{z}$ uwagi na autorytet Komisji Nadzoru Finansowego i możliwość następczego stosowania sankcji nadzorczych.

Można również wskazywać, od strony negatywnej, obszary działalności banków, które nie mogą stać się przedmiotem ich aktywności samoregulacyjnej. Chodzi tu po pierwsze o brak możliwości realizowania kompetencji samoregulacyjnej w sprawach zastrzeżonych ustawą czy wiążącymi aktami prawa UE. Trzeba bowiem uważać, aby nie wkraczać w materię ustawową czy materię aktów prawa UE, gdyż może to powodować jej wypaczenie

17 T. Nieborak, Samoregulacja a rola państwa..., passim.

18 Uchwała nr 141/2017 Komisji Nadzoru Finansowego z dnia 25.04.2017 r. w sprawie wydania rekomendacji KNF H dotyczącej systemu kontroli wewnętrznej w bankach, Dz.Urz. KNF 2017 r., poz. 7.

19 Por. uchwałę nr 183/2014 Komisji Nadzoru Finansowego z dnia 24.06.2014 r. w sprawie wydania Rekomendacji U dotyczącej dobrych praktyk w zakresie bancassurance, Dz.Urz. KNF z 2014 r., poz. 12. 
i wadliwe wykonanie czy przekreślenie procesu konwergencji nadzorczej oraz jednolitego $\mathrm{i}$ jednolicie rozumianego prawa rynku finansowego. Wydaje się jednak $\mathrm{z}$ drugiej strony, że sferą możliwej działalności regulacyjnej instytucji finansowych jest uwzględnianie unijnego soft law ESA, które nie zostało np. przejęte do stosowania przez krajowych regulatorów na podstawie art. 16 rozporządzeń o ESA. Uważać można, że przyjęcie takiego soft law ESA do regulaminów działania czy procedur wewnętrznych w bankach oraz strategii jest nie tylko możliwe, lecz także pożądane, $\mathrm{z}$ uwagi na stosowanie, co do zasady, podwyższonego standardu ochrony klienta i bezpiecznego działania instytucji finansowych. Przy takim podejściu instytucji finansowych ma szansę najpełniej rozwinąć się idea safe habour, czy również - w przypadku teoretycznie możliwych konfliktów - możliwość wykazania przez instytucję finansową należytej staranności profesjonalisty w sytuacji, w której uwzględnia „transponowane” do aktów wewnętrznych instytucji kredytowych soft law unijne. Oczywiście, słaby punkt tego podejścia wyraża się w możliwym twierdzeniu, że skoro krajowy nadzorca nie przejął do stosowania unijnego soft law ESA, to same instytucje finansowe nie będą uwzględniały takiego soft law w swojej działalności, tym bardziej że nie zrobił tego nadzorca krajowy. Nie można jednak wykluczyć, że zwłaszcza w sytuacjach transgranicznych takie podejście może okazać się potrzebne. Rekomendowanym byłoby założenie, że takie podejście mogłyby stosować instytucje finansowe zawsze w przypadku, w którym soft law - stanowiące pewien wzorzec postępowania - zawierałby wyższy standard ochronny dla klienta.

Normatywną granicą dla takiej aktywności instytucji finansowych jest jednak obowiązek poszanowania zasady równej konkurencji na rynku finansowym UE. Z uwagi na to należy uważać i rozważać a casu ad casum, aby działalność samoregulacyjna banków nie powodowała naruszeń tej zasady.

Drugi potencjalny obszar możliwej samoregulacyjnej aktywności banków w sprawach co prawda uregulowanych w ustawie, w których jednak realizacja powinna nastąpić za pomocą wewnętrznych aktów banku, są materie związane $\mathrm{z}$ autonomią zarządzania i organizacją wewnętrzną banku, uregulowane w art. 9 ustawy Prawo bankowe. Postanowienia art. 9-9f ustawy Prawo bankowe są fundamentalne dla zrozumienia idei, treści i funkcji samoregulacji na rynku bankowym i podlegają analizie oraz rekonstrukcji z uwzględnieniem rozporządzenia MF z 2017 r., wydanego w wykonaniu dyspozycji art. 9 f ustawy Prawo bankowe w zakresie zagadnienia kontroli wewnętrznej w bankach.

Zgodnie z art. 9 ustawy Prawo bankowe, na banki nałożono obowiązek wdrożenia systemu zarządzania, który stanowi zbiór zasad i mechanizmów odnoszących się do procesów decyzyjnych zachodzących w banku oraz do oceny prowadzonej działalności bankowej. Tym samym w ten sposób zakreślono ramy działalności samoregulacyjnej, wyznaczając jednak zarazem obowiązkowe treści (w ustawie i konkretyzującym rozporządzeniu MF z 2017 r.), które muszą stać się przedmiotem aktywności wewnątrzregulacyjnej banków, jak i wskazując nowe instytucje do uwzględnienia w wewnętrznych regulacjach bankowych. Trzeba również wspomnieć, że jedną z obligatoryjnych, nowych treści przewidzianych do wdrożenia w wewnętrznych procedurach i standardach banków jest tzw. whistleblowing, co oznacza, że system zarządzania bankiem obejmować musi procedury anonimowego zgłaszania wskazanemu członkowi zarządu, a w szczególnych przypadkach radzie nadzorczej 
banku, naruszeń prawa oraz obowiązujących w banku procedur i standardów etycznych. Przygotowanie przez banki tych procedur i wskazanie treści obligatoryjnej tych procedur nastąpiło w ustawie Prawo bankowe i w rozporządzeniu MF z 2017 r. (art. 9 ust. 2a i 2b ustawy Prawo bankowe).

W ramach procedur whistleblowing ustawodawca wskazał na obowiązek zapewnienia przez bank pracownikom, którzy zgłaszają naruszenia, ochrony co najmniej przed działaniami o charakterze represyjnym, dyskryminacją lub innymi rodzajami niesprawiedliwego traktowania. Uszczegółowiono także, że w ramach systemu zarządzania w banku funkcjonują co najmniej: system zarządzania ryzykiem i system kontroli wewnętrznej. Użyte sformułowanie „co najmniej” oznacza pozostawienie bankom pewnej autonomii w zakresie uregulowania innych jeszcze obszarów w politykach, standardach etycznych i procedurach bankowych, które dopomogłyby w zapewnieniu sprawnego systemu zarządzania w banku. Tym samym ustawodawca określił w tym przypadku pewien minimalny standard regulacyjny przewidziany do wdrożenia w dokumentach wewnętrznych w bankach, wyznaczając silne i skonkretyzowane ramy prawne - granice dla takiej aktywności banków ${ }^{20}$. To na mocy art. 9a ustawy Prawo bankowe nałożono na zarząd banku projektowanie, wprowadzenie oraz zapewnienie działania systemu zarządzania, a na radę nadzorczą banku sprawowanie nadzoru nad wprowadzeniem systemu zarządzania oraz ocenę adekwatności i skuteczności tego systemu.

Na mocy przepisów ustawowych wyznaczono minimalną treść wewnętrznej regulacji bankowej dokonywanej za pomocą dokumentów bankowych, obejmując tą treścią sformalizowane zasady służące określaniu wielkości podejmowanego ryzyka i zasady zarządzania ryzykiem; sformalizowane procedury mające na celu identyfikację, pomiar lub szacowanie oraz monitorowanie ryzyka występującego w działalności banku, uwzględniające również przewidywany poziom ryzyka w przyszłości; sformalizowane limity ograniczające ryzyko i zasady postępowania w przypadku przekroczenia limitów; stosowanie przyjętego systemu sprawozdawczości zarządczej umożliwiającego monitorowanie poziomu ryzyka; posiadanie struktury organizacyjnej dostosowanej do wielkości i profilu ponoszonego przez bank ryzyka. Treści te służą w dużym stopniu wykonaniu przez banki obowiązków i założeń unormowanych w bezpośrednio skutecznym i stosowalnym rozporządzeniu CRR.

Bank, w ramach systemu kontroli zarządczej, zobligowano do wyodrębnienia, po pierwsze, funkcji kontroli mającej za zadanie zapewnienie przestrzegania mechanizmów kontrolnych dotyczących w szczególności zarządzania ryzykiem w banku, która obejmuje stanowiska, grupy ludzi lub jednostki organizacyjne odpowiedzialne za realizację zadań przypisanych tej funkcji; po drugie, komórki do spraw zgodności mającej za zadanie identyfikację, ocenę, kontrolę i monitorowanie ryzyka braku zgodności działalności banku z przepisami prawa, regulacjami wewnętrznymi i standardami rynkowymi oraz przedstawianie raportów w tym zakresie, a także, po trzecie, niezależnej komórki audy tu wewnętrznego mającej za zadanie badanie i ocenę, w sposób niezależny i obiektywny, adekwatności

20 M. Fedorowicz, System zarządzania ryzykiem i system kontroli wewnętrznej w bankach, komentarz praktyczny Lex dla Banków nr 320628, s. 1-10. 
i skuteczności systemu zarządzania ryzykiem i systemu kontroli wewnętrznej, z wyłączeniem komórki audytu wewnętrznego.

Nowym obszarem aktywności wewnątrzregulacyjnej banku jest, zgodnie z art. 9ca ustawy Prawo bankowe, sporządzenie i stosowanie polityki wynagrodzeń dla poszczególnych kategorii osób, których działalność zawodowa ma istotny wpływ na profil ryzyka banku, a która to polityka obejmuje wynagrodzenia i uznaniowe świadczenia emerytalne w rozumieniu art. 4 ust. pkt 73 rozporządzenia nr 575/2013. Obowiązki takie wynikają z regulacji CRR/CRD IV, jednak w znacznej części nałożone zostały również na banki, a dokładniej na zarząd banku, który zobowiązany jest opracować i wdrożyć politykę wynagrodzeń zatwierdzoną przez radę nadzorczą ${ }^{21}$. Nadzór nad tymi nowymi obowiązkami banków sprawuje KNF, która gromadzi i analizuje informacje publikowane przez banki, zgodnie z art. 450 ust. 1 rozporządzenia nr 575/2013, w celu monitorowania tendencji i praktyk w zakresie polityki wynagrodzeń stosowanej przez banki. Obowiązkiem banku jest również raz do roku, w terminie do dnia 31 stycznia, przekazanie KNF danych o liczbie osób, których działalność zawodowa ma istotny wpływ na profil ryzyka banku, a których łączne wynagrodzenie w poprzednim roku wyniosło co najmniej równowartość $1 \mathrm{mln}$ EUR, wraz z informacjami dotyczącymi stanowisk zajmowanych przez te osoby oraz wartości głównych składników wynagrodzenia, przyznanych premii, nagród długookresowych oraz odprowadzonych składek emerytalnych.

Zgodnie z rozwijającym zapisy ustawy Prawo bankowe $\$ 18$ rozporządzenia MF z 2017 r., system zarządzania ryzykiem jest elementem składowym strategii zarządzania ryzykiem przez bank, na którą składają się rozbudowane polityki i procedury zarządzania ryzykiem w odniesieniu do poszczególnych jego rodzajów w działalności bankowej. To właśnie strategie, polityki i procedury zarządzania ryzykiem stanowią obszar aktywności wewnątrzregulacyjnej banków. W rozporządzeniu doprecyzowano przede wszystkim to, jakie obowiązki spoczywają na banku w ramach funkcji kontroli, a jest to obowiązek posiadania mechanizmów kontrolnych, niezależnego monitorowania przestrzegania mechanizmów kontrolnych i raportowania w ramach funkcji kontroli (\$35 rozporządzenia MF z 2017 r.), które również można zaliczyć do obszarów podlegających konkretyzacji w drodze wewnętrznych strategii, polityk i procedur bankowych. W odniesieniu do procedur związanych z whistleblowing w $\$ 45$ ust. 4 rozporządzenia MF z 2017 r. unormowano warunki brzegowe, w ramach których bank powinien ukształtować tę procedurę. Procedura ta ma m.in. uwzględniać możliwość odbierania zgłoszeń bez podawania tożsamości przez pracownika dokonującego zgłoszenia; sposób ochrony pracownika dokonującego zgłoszenia, zapewniający co najmniej ochronę przed działaniami o charakterze represyjnym, dyskryminacją lub innymi rodzajami niesprawiedliwego traktowania; czy wskazanie osób odpowiedzialnych za odbieranie zgłoszeń naruszeń, sposób ich przekazywania członkowi zarządu oraz ich weryfikacji.

Odnosząc zagadnienie samoregulacji do poziomu UE, można wysunąć tezę, że zarówno prawodawca UE, jak i nadzorcy unijni również częściej i chętniej posługują się wiążący-

21 M. Fedorowicz, Polityka wynagrodzeń w bankach w świetle regulacji dyrektywy CRD IV i rozporządzenia CRR, komentarz praktyczny Lex dla Banków nr 199965, s. 1-13. 
mi instrumentami prawnymi (nadzorcy) czy unifikują materię prawa rynku finansowego (prawodawca UE), szczególnie newralgiczną z punktu widzenia zapewnienia stabilności finansowej $\mathrm{w}$ bezpośrednio skutecznych i stosowalnych rozporządzeniach oraz za pomocą BTS-ów. W Europejskim Systemie Nadzoru Finansowego nawet soft law Europejskich Organów Nadzoru Finansowego można - jak się wydaje - nazwać miękkim prawem nowej generacji, które w istocie wymusza swoje stosowanie. Z kolei w ramach powstałej Europejskiej Unii Bankowej, w jej filarze nadzoru bankowego (ang. Single Supervision Mechanism, jednolity nadzór bankowy), Europejski Bank Centralny, jako swoisty supernadzorca nad rynkiem bankowym, wydaje nawet rozporządzenia nadzorcze adresowane do krajowych nadzorców strefy euro, wskazując im wiążąco sposób postępowania ${ }^{22}$. Powoduje to następnie wyznaczanie nowych zadań i obowiązków instytucjom kredytowym (finansowym), co związane jest z powinnościami raportacyjnymi i sprawozdawczymi zarówno z zakresu nadzoru mikroostrożnościowego, jak i makroostrożnościowego. Zwrócić można uwagę choćby na soft law, formalnie niewiążące, które jednak wchodzi do polskiego prawa bankowego na podstawie art. 133 ust. la ustawy Prawo bankowe ${ }^{23}$, a następnie zapewnia się mu miejsce w rekomendacjach Komisji Nadzoru Finansowego, ponownie również niewiążących, ale respektowanych na rynku finansowym $z$ uwagi na jej autorytet nadzorczy ${ }^{24}$. Istotnym argumentem $\mathrm{w}$ dyskusji dotyczącej ograniczenia zdolności samoregulacyjnych instytucji kredytowych (finansowych) są również unormowania rozporządzeń o Europejskich Organach Nadzoru Finansowego (EONF), na podstawie których organy te, w szczególnych okolicznościach mogą pozyskiwać informacje bezpośrednio od instytucji kredytowych (każdorazowo art. 35 ust. 6 rozporządzeń o EONF) lub nawet wydawać wytyczne i zalecenia bezpośrednio do instytucji finansowych, zgodnie każdorazowo z art. 16 ust. 1 rozporządzeń o $\mathrm{EONF}^{25}$.

22 Europejski Bank Centralny, na podstawie art. 6 ust. 3 (i odpowiednio art. 4 ust. 3) rozporządzenia 1024/2013, ma kompetencję do wydawania wiążących instrukcji (wytycznych) oraz rozporządzeń mających na celu realizację i konkretyzację kompetencji nadzorczych, zob. rozporządzenie Rady (UE) nr 1024/2013 z dnia 15 października 2013 r. powierzające Europejskiemu Bankowi Centralnemu szczególne zadania w odniesieniu do polityki związanej z nadzorem ostrożnościowym nad instytucjami kredytowymi, Dz.Urz. UE L 287 z 29.10.2013, s. 63.

23 M. Fedorowicz, Nadzorcze soft law nowej generacji w sektorze bankowym w świetle art. 133 ust. 1a ustawy Prawo bankowe”, „Studia Prawnoustrojowe” 2017, nr 38, s. 29-44.

24 E. Fojcik-Mastalska, Podustawowe źródła prawa bankowego po nowelizacji, „Prawo Bankowe” 2002, nr 4, s. 52 i n.; eadem, Akty podustawowe, w: Prawo bankowe, eadem, Wydawnictwo Uniwersytetu Wrocławskiego, Wrocław 2009, s. 19; M. Olszak, Bankowe normy ostrożnościowe, Temida 2, Białystok 2011, s. 156 i n.; B. Smykla, Prawo bankowe. Komentarz, C.H. Beck, Warszawa 2011, s. 704; R. Tupin, Status prawny i kompetencje prawotwórcze organów Narodowego Banku Polskiego i Komisji Nadzoru Bankowego, „Przegląd Ustawodawstwa Gospodarczego” 1998, nr 7-8, s. 9; L. Góral, Komentarz do art. 137 ustawy Prawo bankowe, w: Prawo bankowe. Komentarz, red. E. Fojcik-Mastalska, wyd. 4, LexisNexis, Warszawa 2005, s. 631-635; R. Kaszubski, Funkcjonalne źródła prawa bankowego publicznego, Zakamycze, Warszawa 2006 oraz uzasadnienie orzeczenia TK 25/99 i przywoływana tam dyskusja przedstawicieli doktryny.

25 Rozporządzenie Parlamentu Europejskiego i Rady (UE) nr 1093/2010 z dnia 24 listopada 2010 r. w sprawie ustanowienia Europejskiego Urzędu Nadzoru (Europejskiego Urzędu Nadzoru Bankowego), zmiany decyzji nr 716/2009/ WE oraz uchylenia decyzji Komisji 2009/78/WE, Dz.Urz. L 331 z 15.12.2010, s. 12 ze zm.; rozporządzenie Parlamentu Europejskiego i Rady (UE) nr 1095/2010 z dnia 24 listopada 2010 r. w sprawie ustanowienia Europejskiego Urzędu Nadzoru (Europejskiego Urzędu Nadzoru Giełd i Papierów Wartościowych), zmiany decyzji nr 716/2009/WE i uchylenia decyzji Komisji 2009/77/WE, Dz.Urz. UE L 331 z 15.12.2010, s. 84 ze zm.; rozporządzenie Parlamentu Europejskiego i Rady (UE) nr 1094/2010 z dnia 24 listopada 2010 r. w sprawie ustanowienia Europejskiego Urzędu Nadzoru (Europejskiego Urzędu Ubezpieczeń i Pracowniczych Programów Emerytalnych), zmiany decyzji nr 716/2009/WE i uchylenia decyzji Komisji 2009/79/WE, Dz.Urz. UE L 331 z 15.12.2010, s. 48 ze zm. 


\section{Podsumowanie}

Warto zwrócić uwagę, że zjawisko tzw. samoregulacji na rynku finansowym przeszło ewolucję. Zmiana paradygmatu regulacyjnego na nadzorczy spowodowała, że coraz więcej obszarów dotąd nieregulowanych, albo pozostawionych regulacji za pomocą instrumentów soft law, zaczyna być normowana wiążącymi instrumentami prawnymi. Przykładem takiej - dotąd nieregulowanej materii nadzorczej - są wiążące postanowienia buforowe, które dzięki regulacji CRR/CRD IV zostały wdrożone do ustawodawstw państw członkowskich, podobnie jak utworzone krajowe ramy prawne nadzoru makroostrożnościowego. Na rynku finansowym po kryzysie finansowym i z uwagi na potrzebę wzmocnienia ochrony klienta przeważają regulacje publicznoprawne. Na pytanie, czy regulacje na rynku finansowym z uwagi na konieczność zapewnienia bezpieczeństwa i stabilności finansowej powinny mieć bardziej charakter publiczny czy prywatny, można odpowiedzieć na korzyść regulacji publicznoprawnych, nadzorczych. Wydaje się bowiem, że w ostatnim czasie, zwłaszcza po kryzysie finansowym, regulacje na rynku finansowym UE przybrały zdecydowanie charakter publicznoprawny. Może to oznaczać, że samoregulacja instytucji kredytowych czy szerzej finansowych traktowana jest jako zjawisko nieprzyczyniające się do minimalizacji ryzyka powstającego na rynku finansowym, co więcej, jego ograniczenie może być i wydaje się, że jest pojmowane, jako wzmacniające jednolitość nadzorczą oraz jednolite rozumienie i stosowanie przepisów nadzorczych. Ponadto, skoro samoregulacja instytucji finansowych nie działa, jak stwierdzono w próżni prawnej, to warto też zauważyć, że jej pole podlega stopniowemu zawężeniu. Rozporządzenie MF z 2017 r. pokazuje, że to samoregulacyjne pole instytucji finansowych, wyrażające się w możliwości tworzenia polityk, strategii, planów awaryjnych otrzymuje bardziej sztywne niż dotychczas ramy prawne, zacieśniając jednak możliwości samoregulacyjne. Jest to wyrazem konieczności wzmocnienia procesu nadzorczej integracji na rynku finansowym, zarówno w podejściu mikroostrożnościowym, makroostrożnościowym, jak i w związku z ochroną klienta oraz zapewnienia funkcjonalnych, wykonawczych połączeń między aktami prawa bankowego UE a aktami prawa polskiego.

Proces silnej integracji nadzorczej może być choćby rekonstruowany przez analizę art. 9-9f ustawy Prawo bankowe, dokonywaną w ujęciu historycznym w zakresie zmian kształtu normatywnego tego zespołu przepisów na przestrzeni lat ${ }^{26}$. Jest to tylko przykład, jeden z wybranych, gdyż oczywiście normatywizowanie funkcjonowania rynku finansowego, postępująca integracja nadzorcza, rozwój i uszczegółowienie przepisów prawnorynkowych jest pewną ogólną tendencją tak prawodawcy UE, jak i krajowego, i to nie tylko w obszarze prawa rynku finansowego.

Ciekawe jest również to, że współczesne soft law wymusza swoje stosowanie i ogranicza pole samoregulacji instytucji finansowych, bo jest włączane do krajowego porządku

$26 \mathrm{Na}$ temat systemu zarządzania bankiem zob. zwłaszcza E. Fojcik-Mastalska, System zarządzania bankiem w ujęciu prawnym, „Ruch Prawniczy, Ekonomiczny i Socjologiczny” 2012, nr 4, s. 5-16; S. Szuster, Komentarz do art. 9 ustawy Prawo bankowe, w: Prawo bankowe. Komentarz, t. 1, red. F. Zoll, Zakamycze, Warszawa 2005 i Z. Ofiarski, Komentarz do art. 9 ustawy - Prawo bankowe, w: idem, Prawo bankowe. Komentarz, Lex Wolters Kluwer, Warszawa 2013. 
prawnego w działalności KNF (zob. np. art. 131 ust. la prawa bankowego ${ }^{27}$ ). Wskazuje to ponownie na ograniczenie pola samoregulacyjnego. Trzeba zauważyć, że proces wzmocnionej integracji nadzorczej, toczący się na rynku finansowym od dłuższego już czasu, jeszcze przed kryzysem finansowym, obecnie mocno dotyka tzw. upodmiotowienia instytucji finansowych.

Można też wskazać, że przecież nawet regulacje rdzennie wyrastające $\mathrm{z}$ obszaru norm prawa prywatnego stają się istotne dla nadzoru makroostrożnościowego, gdyż uzyskują doniosłość makroostrożnościową. Przykładem takiej treści prawnorynkowej o doniosłości makroostrożnościowej, a więc pozostającej w polu zainteresowania nadzorcy makroostrożnościowego są postanowienia ustawy o kredycie hipotecznym i nadzorze nad pośrednikami kredytu hipotecznego i agentami ${ }^{28}$. Analiza treści tej ustawy pozwala stwierdzać, że jej treść w dużym stopniu powieliła i skonkretyzowała rekomendację S Komisji Nadzoru Finansowego $^{29}$, co spowodowało de iure normatywizację znacznej części tej rekomendacji w ustawie.

Niewątpliwie zmienia się również pojęcie, treść i funkcje samoregulacji. Skoro rynek finansowy ma podwójny, gdyż unijno-krajowy nadzór z realnymi instrumentami oddziaływania na rynek finansowy z poziomu UE (np. za pomocą decyzji Europejskich Organów Nadzoru Finansowego, czy za pomocą BTS-ów) oraz soft law nadzorczego nowej generacji, które wchodzi do krajowego porządku prawnego, na podstawie art. 133 ust. la ustawy Prawo bankowe, to $\mathrm{w}$ istocie możliwości samoregulacyjnych jest na rynku finansowym coraz mniej, co oczywiście jest wyrazem pokryzysowej filozofii regulacyjnej i silniejszego związania instytucji kredytowych wiążącymi regulacjami i instrumentami stosowania prawa. Charakterystyczne jest również i to, że następuje coraz mocniejsza normatywizacja obszarów dotąd niezagospodarowanych nadzorczo czy niezagospodarowanych aż tak intensywnie (whistleblowing czy polityka wynagrodzeń, jak i obszar ujawnień), a coraz więcej zmian można obserwować również w zakresie przesunięcia akcentów normatywnych z soft law na hard law w prawie rynku finansowego ${ }^{30}$. Dokonujące się zmiany można najlepiej zaobserwować w swoistym „bankowym mierniku” zdolności samoregulacyjnych instytucji kredytowych, a mianowicie w instytucji kontroli wewnętrznej, która w ostatnim dziesięcioleciu (1997-2017/2018) przechodziła wiele zmian, z praktycznie jednoartykułowego unormowania, stając się rozbudowaną konstrukcją przepisów z jednej strony dającą pewne możliwości samoregulacji, jednak z drugiej, obecnie zacieśniającą wyznaczone pole normatywne, w ramach którego może się ona dokonywać, co wydaje się uzasadnione z punktu widzenia urzeczywistnienia celów regulacji prawnorynkowych.

27 Zob. T. Nieborak, Soft lex, sed lex? O nowych formach regulacji rynku finansowego Unii Europejskiej, „Przegląd Zachodni" 2017, nr 2, passim; M. Fedorowicz, Nadzorcze soft law nowej generacji..., s. 29-44.

28 M. Fedorowicz, Postanowienia ustawy z dnia 23 marca 2017 r. o kredycie hipotecznym oraz o nadzorze nad pośrednikami kredytu hipotecznego i agentami oraz rekomendacji S Komisji Nadzoru Finansowego a zapobieganie kryzysom bankowości hipotecznej, „Studia Prawa Publicznego” 2017, nr 4, s. 9 i n.

29 Zob. uchwała nr 148/2013 Komisji Nadzoru Finansowego z dnia 18 czerwca 2013 r. w sprawie wydania Rekomendacji S dotyczącej dobrych praktyk w zakresie zarządzania ekspozycjami kredytowymi zabezpieczonymi hipotecznie, Dz.Urz. KNF z 2013 r., poz. 23.

30 D. Wojtczak-Samoraj, op. cit., s. 59. 
Przez pojęcie samoregulacji instytucji finansowych, w wyniku zmienionego na rynku finansowym UE paradygmatu regulacyjnego, rozumieć można kompetencję instytucji finansowych do wydawania norm postępowania, tworzenia standardów postępowania, w tym również etycznych służących wewnętrznej organizacji i funkcjonowaniu tych instytucji w przewidzianych, obowiązujących ramach prawnych, określonych zarówno w prawie rynku finansowego na poziomie UE, jak i krajowym. Zmiana w porównaniu z okresem wcześniejszym polega jednak na tym, że jeśli wcześniej kompetencja ta delegowana była głównie przez ustawodawców i nadzorców krajowych, to obecnie pochodzi ona również od prawodawcy i nadzorców unijnych mikroostrożnościowych i makroostrożnościowych i jest słusznie podporządkowana osiągnięciu celu stabilności finansowej i bardziej efektywnemu wykonaniu prawa UE oraz jednolitemu jego rozumieniu i stosowaniu w procesie konwergencji nadzorczej, co powoduje ograniczenie zakresu samoregulacji. Z uwagi na skomplikowanie produktów i usług finansowych oferowanych konsumentowi tego rynku, jak i z uwagi na to, że ryzyko działalności bankowej, w tym również związane z innowacjami technicznymi oraz zarządzanie tym ryzykiem, tworzy niebezpieczeństwa dla systemu finansowego, zasadne wydaje się ograniczenie możliwości samoregulacyjnych instytucji kredytowych czy szerzej finansowych. Jest to wyrazem przyjętej filozofii regulacyjnej i nadzorczej narracji na rynku finansowym UE. Trzeba jednak podkreślić, że ta nadzorcza narracja regulacyjna przejawia się na rynku finansowym UE nie tylko w normatywizacji różnych, dotąd niezagospodarowanych obszarów czy intensyfikacji integracji nadzoru, ale właśnie w procesie nadzorczej konwergencji sieciowej, gdzie wszelkie instrumenty i mechanizmy integracji nadzorczej rozpatrywane są przez pryzmat funkcjonalnie postrzeganych zadań i obowiązków podmiotów sieci stabilności finansowej. W dużym stopniu jednak możliwości samoregulacyjne instytucje kredytowe mogą realizować w ramach wprowadzanych norm etycznych, w tym powstających kodeksów rzetelnej praktyki bankowej.

\section{Bibliografia}

Fedorowicz M., Nadzorcze soft law nowej generacji w sektorze bankowym w świetle art. 133 ust. 1a ustawy Prawo bankowe”, „Studia Prawnoustrojowe” 2017, nr 38.

Fedorowicz M., Nadzór nad rynkiem finansowym Unii Europejskiej, Difin, Warszawa 2013.

Fedorowicz M., Obowiązki informacyjne i ujawnienia nałożone na banki w świetle rozporządzenia $C R R$, komentarz praktyczny Lex dla Banków nr 193490.

Fedorowicz M., Polityka wynagrodzeń w bankach $w$ świetle regulacji dyrektywy CRD IV i rozporzadzenia CRR, komentarz praktyczny Lex dla Banków nr 199965, s. 1-13.

Fedorowicz M., Postanowienia ustawy z dnia 23 marca 2017 r. o kredycie hipotecznym oraz o nadzorze nad pośrednikami kredytu hipotecznego i agentami oraz rekomendacji S Komisji Nadzoru Finansowego a zapobieganie kryzysom bankowości hipotecznej, „Studia Prawa Publicznego” 2017, nr 4.

Fedorowicz M., System zarzadzania ryzykiem i system kontroli wewnętrznej w bankach, komentarz praktyczny Lex dla banków nr 320628, s. 1-10.

Fojcik-Mastalska E., Akty podustawowe, w: Prawo bankowe, red. eadem, Wydawnictwo Uniwersytetu Wrocławskiego, Wrocław 2009. 
Fojcik-Mastalska E., Podustawowe źródła prawa bankowego po nowelizacji, „Prawo Bankowe” 2002, nr 4.

Fojcik-Mastalska E., System zarzadzania bankiem w ujęciu prawnym, „Ruch Prawniczy, Ekonomiczny i Socjologiczny" 2012, nr 4, s. 5-16.

Góral L., Komentarz do art. 137 ustawy Prawo bankowe, w: Prawo bankowe. Komentarz, red. E. Fojcik-Mastalska, wyd. 4, LexisNexis, Warszawa 2005.

Jurkowska-Zeidler A., Bezpieczeństwo rynku finansowego w świetle prawa Unii Europejskiej, Wolters Kluwer, Warszawa 2008.

Jurkowska-Zeidler A., Europejska Unia Bankowa. Architektura instytucjonalna, w: Instytucje prawnofinansowe w warunkach kryzysu gospodarczego, red. W. Miemiec, K. Sawicka, Wolters Kluwer, Warszawa 2014.

Jurkowska-Zeidler A., Prawo Unii Bankowej, „Analiza Natolińska” 2016, nr 1.

Jurkowska-Zeidler A., Zmiany w otoczeniu regulacyjnym rynku finansowego Unii Europejskiej, $\mathrm{w}$ : XXV lat przeobrażeń w prawie finansowym i prawie podatkowym. Ocena dokonań $i$ wnioski na przyszłość, red. Z. Ofiarski, Wydział Prawa i Administracji Uniwersytetu Szczecińskiego, Szczecin 2014.

Kaszubski R., Funkcjonalne źródła prawa bankowego publicznego, Kantor Wydawniczy Zakamycze, Kraków 2006.

Knepka T., Rola Europejskiego Banku Centralnego w zapewnieniu stabilności rynku finansowego Unii Europejskiej, Instytut Wydawniczy EuroPrawo, Warszawa 2017.

Menkes M., Governance gospodarczy. Studium prawnomiędzynarodowe, C.H. Beck, Warszawa 2016.

Michór A., Nowa europejska architektura nadzoru nad rynkiem bankowym, „Bezpieczny Bank” 2011, nr 1, s. 71-90.

Nieborak T., Samoregulacja a rola państwa $w$ sferze regulacji rynku finansowego, w: Własność $i$ kontrola $w$ teorii i praktyce, red. B. Polszakiewicz, J. Boehlke, (Ekonomia i Prawo, t. 3), Wydawnictwo Uniwersytetu Mikołaja Kopernika, Toruń 2007.

Nieborak T., Soft lex, sed lex? O nowych formach regulacji rynku finansowego Unii Europejskiej, „Przegląd Zachodni” 2017, nr 2.

Ofiarski Z., Komentarz do art. 9 ustawy - Prawo bankowe, w: idem, Prawo bankowe. Komentarz, Lex Wolters Kluwer, Warszawa 2013.

Olszak M., Bankowe normy ostrożnościowe, Temida 2, Białystok 2011.

Smykla B., Prawo bankowe. Komentarz, C.H. Beck, Warszawa 2011.

Szuster S., Komentarz do art. 9 ustawy Prawo bankowe, w: Prawo bankowe. Komentarz, t. 1, red. F. Zoll, Kantor Wydawniczy Zakamycze, Kraków 2005.

Tupin R., Status prawny i kompetencje prawotwórcze organów Narodowego Banku Polskiego i Komisji Nadzoru Bankowego, „Przegląd Ustawodawstwa Gospodarczego” 1998, nr 7-8.

Wojtczak-Samoraj D., Soft law i mechanizmy nielegislacyjne jako instrumenty integracji rynku usług bankowych Unii Europejskiej, „Monitor Prawa Bankowego” 2012, nr 1.

\section{Akty prawa oraz inne akty}

Rozporządzenie Parlamentu Europejskiego i Rady (UE) nr 1093/2010 z dnia 24 listopada 2010 r. w sprawie ustanowienia Europejskiego Urzędu Nadzoru (Europejskiego Urzędu Nadzoru Bankowego), zmiany decyzji nr 716/2009/WE oraz uchylenia decyzji Komisji 2009/78/WE, Dz.Urz. L 331 z 15.12.2010, s. 12 ze zm. 
Rozporządzenie Parlamentu Europejskiego i Rady (UE) nr 1094/2010 z dnia 24 listopada 2010 r. w sprawie ustanowienia Europejskiego Urzędu Nadzoru (Europejskiego Urzędu Ubezpieczeń i Pracowniczych Programów Emerytalnych), zmiany decyzji nr 716/2009/WE i uchylenia decyzji Komisji 2009/79/WE, Dz.Urz. UE L 331 z 15.12.2010. s. 48 ze zm.

Rozporządzenie Parlamentu Europejskiego i Rady (UE) nr 1095/2010 z dnia 24 listopada 2010 r. w sprawie ustanowienia Europejskiego Urzędu Nadzoru (Europejskiego Urzędu Nadzoru Giełd i Papierów Wartościowych), zmiany decyzji nr 716/2009/WE i uchylenia decyzji Komisji 2009/77/WE, Dz.Urz. UE L 331 z 15.12.2010, s. 84 ze zm.

Rozporządzenie Parlamentu Europejskiego i Rady nr 575/2013 z dnia 26 czerwca 2013 r. w sprawie wymogów ostrożnościowych dla instytucji kredytowych i firm inwestycyjnych, zmieniające rozporządzenie (UE) nr 648/2012, Dz.Urz. UE L 176 z 27.06. 2013, s. 1 ze zm.

Rozporządzenie Rady (UE) nr 1024/2013 z dnia 15 października 2013 r. powierzające Europejskiemu Bankowi Centralnemu szczególne zadania w odniesieniu do polityki związanej z nadzorem ostrożnościowym nad instytucjami kredytowymi, Dz.Urz. UE L 287 z 29.10.2013, s. 63.

Rozporządzenie Ministra Rozwoju i Finansów z dnia 6 marca 2017 r. w sprawie systemu zarządzania ryzykiem i systemu kontroli wewnętrznej, polityki wynagrodzeń oraz szczegółowego sposobu szacowania kapitału wewnętrznego w bankach, Dz.U. z 2017 r., poz. 637.

Dyrektywa 2013/36/UE Parlamentu Europejskiego i Rady z dnia 26 czerwca 2013 r. w sprawie warunków dopuszczenia instytucji kredytowych do działalności oraz nadzoru ostrożnościowego nad instytucjami kredytowymi i firmami inwestycyjnymi, zmieniająca dyrektywę 2002/87/WE i uchylająca dyrektywy 2006/48/WE oraz 2006/49/WE, Dz.Urz. UE L 176 z 27.06.2013, s. 338 ze zm.

Ustawa z dnia 29 sierpnia 1997 r. Prawo bankowe, tekst jedn.: Dz.U. z 2017 r., poz. 1876 ze zm.

Uchwała nr 148/2013 Komisji Nadzoru Finansowego z dnia 18 czerwca 2013 r. w sprawie wydania Rekomendacji S dotyczącej dobrych praktyk w zakresie zarządzania ekspozycjami kredytowymi zabezpieczonymi hipotecznie, Dz.Urz. KNF z 2013 r., poz. 23.

Uchwała nr 141/2017 Komisji Nadzoru Finansowego z dnia 25.04.2017 r. w sprawie wydania rekomendacji KNF H dotyczącej systemu kontroli wewnętrznej w bankach, Dz.Urz. KNF 2017 r., poz. 7.

Uchwała nr 183/2014 Komisji Nadzoru Finansowego z dnia 24.06.2014 r. w sprawie wydania Rekomendacji U dotyczącej dobrych praktyk w zakresie bancassurance, Dz.Urz. KNF z 2014 r., poz. 12 .

\section{A few remarks on the phenomenon of the self-regulation on the banking sector in the new supervisory architecture}

\section{SUMMARY}

The aim of the paper $A$ few remarks on the phenomenon of the self-regulation on the banking sector in the new supervisory architecture is to analyze the phenomenon of the self-regulation and its question and meaning for the functioning of the financial institutions in the new financial regulatory architecture, established by European System of Financial Supervision and the European Banking Union. The thesis and conclusions of this paper concern the issue of reducing the phenomenon of self-regulation on the financial market (in this paper in banking sector) and changes in the content of the term "self-regulation” and also underscore the role of hard law and binding supervisory instruments on the financial market 
after the crisis, due to new supervisory regulatory paradigm. The analysis of this paper were discussed on the example of Polish Banking Law Act, especially in the area of internal banking risk management, the internal banking supervision and whistleblowing for defending the conclusions presented in this paper.

KEYWORDS

self-regulation, financial market of the EU, supervisory architecture of the EU, self-regulation issues, internal banking supervision 